\title{
FAKTOR FISIOLOGI TERUKUR YANG MEMPENGARUHI PRODUKTIVITAS TENAGA KERJA KONSTRUKSI
}

\author{
Felix Hartanto ${ }^{1}$, Basuki Anondho ${ }^{2}$, Meiske Yunithree Suparman ${ }^{3}$ \\ ${ }^{1}$ Program Studi Teknik Sipil, Universitas Tarumanagara \\ Surel: felix_hartanto93@yahoo.com \\ ${ }^{2}$ Jurusan Teknik Sipil, Universitas Tarumanagara \\ Surel: basukia@ft.untar.ac.id \\ ${ }^{3}$ Jurusan Psikologi, Universitas Tarumanagara
}

\begin{abstract}
ABSTRAK
Produktivitas merupakan bagian mendasar dari informasi untuk memperkirakan dan menjadwalkan proyek konstruksi. Salah satu faktor yang mempengaruhi produktivitas adalah kinerja tenaga kerja konstruksi. Mengukur kinerja tenaga kerja konstruksi diperlukan alat ukur dengan pertimbangan variabel terukur sebagai masukan. Beberapa penelitian terdahulu menunjukan adanya beberapa faktor fisiologi yang berpengaruh. Penelitian ini mencoba mengidentifikasi faktor-faktor fisiologis dominan yang mempengaruhi tenaga kerja konstruksi dan memperoleh faktor fisiologis terukur yang dapat digunakan sebagai dasar perhitungan produktivitas tenaga kerja konstruksi. Metode pembahasan dimulai dari tahap mencari faktor pengaruh melalui studi literatur. Tahap selanjutnya adalah merumuskannya menjadi kuesioner dan mendistribusikan kepada tenaga kerja konstruksi. Tahap terakhir yaitu pengolahan data menggunakan analisis faktor. Hasil penelitian didapat 4 variabel laten baru dengan 7 indikator fisiologi sebagai faktor yang mempengaruhi produktivitas tenaga kerja.
\end{abstract}

Kata kunci: Kinerja, Faktor Dominan, Fisiologi, Tenaga Kerja Konstruksi, Produktivitas

\section{ABSTRACT}

Productivity is a fundamental part of information for estimating and scheduling construction projects. One of the factors that increase productivity is the performance of construction labor. To measure construction labor performance, a scale with measured variable consideration is needed as an input. Several studies have identified several influential physiological factors. This study tries to identify dominant physiological factors that affects construction labor and obtain measurable physiological factors that can be used as a basis for calculating the productivity of construction labor. The method of discussion begins by seeking influential factors through literature studies. The next step is formulating it into a questionnaire and distributing it to construction workers. The last step is data processing using factor analysis. The result yields 4 new latent variables with 7 physiological indicators as factors that influence labor productivity.

Keywords: Performance, Dominant Factors, Physiology, Construction Workers, Productivity

\section{PENDAHULUAN}

\section{Latar Belakang}

Proyek konstruksi dapat berjalan sukses atau tidaknya bergantung pada efektifitas pengelolaan sumber daya manusia (Wulfram, 2005). Sumber daya manusia (tenaga kerja) merupakan salah satu faktor penentu keberhasilan suatu proyek konstruksi (Soeharto, 1997). Keberhasilan suatu 
proyek berhubungan dengan produktivitas tenaga kerja, jika produktivitasnya tinggi maka keberhasilan proyek akan lebih tinggi begitu juga berlaku sebaliknya.

Produktivitas tenaga kerja merupakan bagian mendasar dari informasi untuk memperkirakan dan menjadwalkan proyek konstruksi (Song, 2008). Produktivitas menjadi salah satu faktor penentu dalam waktu penyelesaian proyek, dimana produktivitas merupakan rasio antara output dengan input, atau rasio antara hasil produksi dengan total sumber daya yang digunakan. Salah satu faktor yang mempengaruhi produktivitas ialah kinerja tenaga kerja. Tenaga kerja memiliki peran yang sangat penting dalam meningkatkan kinerja konstruksi (Jergeas, 2010; Castaneda et al, 2003; 2005).

Mengukur kinerja produktivitas konstruksi diperlukan alat ukur dengan pertimbangan variabel terukur sebagai masukan. Beberapa peneliti terdahulu menunjukan adanya beberapa faktor fisiologi yang berpengaruh. Faktor fisiologi berpengaruh terhadap kelelahan kerja. Kelelahan kerja menyebabkan berkurangnya produktivitas dan motivasi, ketidakteraturan bekerja, penilaian yang buruk, kualitas pekerjaan yang buruk, ketidakpuasan hasil kerja, kecelakaan dan cedera (Brouha, 1967 dan Janaro, 1982).

Penelitian ini mencoba mengidentifikasi faktor-faktor fisiologi dominan yang mempengaruhi tenaga kerja konstruksi dan memperoleh faktor fisiologi terukur yang dapat digunakan sebagai dasar perhitungan produktivitas tenaga kerja konstruksi.

\section{RUMUSAN MASALAH}

\section{Fisiologi Kerja}

Fisiologi kerja adalah disiplin ilmu yang berkaitan dengan pemahaman metabolik dan respon fisiologi terhadap pekerjaan manual (Abdelhamid dan Everett, 2002). Fokus utama dari fisiologi kerja adalah mencegah pekerja mengalami kelelahan fisik dengan mengurangi tuntutan pekerjaan (Astrand dan Rodahl, 1986).

Fisiologi kerja dan prinsipnya (Abdelhamid dan Everett, 2002):

\section{Mengukur permintaan fisiologi}

Tugas dasar fisiologi pekerjaan adalah mengukur kemampuan pekerja melakukan aktivitas pekerjaan konstruksi tertentu berdasarkan beban kerja dan menganalisa terhadap kemampuan pekerja untuk melakukan pekerjaan itu (Astrand dan Rodahl 1986). Beban kerja diukur menggunakan penyerapan oksigen maksimal dan denyut jantung.

\section{Mengukur pengeluaran energi}

Kkal adalah unit yang digunakan untuk mengukur energi, baik saat bekerja maupun istirahat. Ada 2 cara mengukur pengeluaran energi, yaitu kalorimetri langsung dan kalorimetri tidak langsung.

\section{Pengukuran penyerapan oksigen}

Pengukuran menggunakan kalorimetri tidak langsung terdapat 2 teknik penggunaannya yaitu, sistem tertutup dan sistem terbuka.

4. Metode untuk mengevaluasi tingkat keparahan kerja 
Tujuannya untuk mengidentifikasi keparahan kerja yang ditimbulkan. Terdapat indikator tingkat keparahan kerja berdasarkan Astrand dan Rodahl (1986); Christensen (1983).

\section{Menggunakan pengeluaran energi absolut sebagai kriteria beban kerja}

Menurut Broha (1967), para pekerja harus beristirahat sampai fungsi fisiologis, seperti denyut jantung, tekanan darah, penyerapan oksigen, tingkat keringat, suhu tubuh, komposisi kimia darah dan urine, kembali normal. Ketika pekerjaan mekanik berhenti, pekerja fisiologis tetap bekerja sampai pemulihan telah selesai (Brouha 1967).

\section{Denyut jantung sebagai kriteria beban kerja}

Menurut Brouha (1967), denyut jantung rata-rata ialah 110 beats per menit selama 8 jam kerja. Beberapa peneliti melakukan riset terhadap denyut jantung ketika beristirahat dengan denyut jantung ketika bekerja. Umumnya tingkat kebugaran, durasi kerja, dan tingkatan stres dari pekerja sangat berpengaruh terhadap denyut jantung.

\section{METODE PENELITIAN}

\section{Studi literatur}

Berdasarkan jurnal, buku, dan penelitian terdahulu mengenai faktor fisiologi yang mempengaruhi produktivitas tenaga kerja konstruksi.

\section{Identifikasi Variabel Fisiologi Berdasarkan Studi Literatur.}

Mengidentifikasi variabel fisiologi apa saja yang ditemukan dari studi literatur. Terdapat 21 variabel yang diwakilkan dengan 10 indikator fisiologi.

Indikator: (1) pengeluaran energi, (2) ergonomi, (3) konsumsi oksigen, (4) denyut nadi, (5) suhu tubuh, (6) mental, (7) emosi, (8) stress, (9) kecepatan tubuh, (10) otot.

Variabel: (1) pekerjaan berat, (2) pekerjaan ringan, (3) pekerjaan melelahkan, (4) beban kerja, (5) alat, (6) penggunaan alat membantu pekerjaan, (7) menyukai pekerjaan, (8) pekerjaan melelahkan, (9) libur, (10) istirahat malam, (11) banyak tenaga, (12) berkeringat, (13) udara segar, (14) mudah lapar, (15) nafas terengah-engah, (16) berdebar-debar, (17) jarak rumah ke proyek, (18) jarak antar bengkel di proyek, (19) mental, (20) emosi, (21) stress

\section{Penyusunan Kuesioner}

Menyusun kuesioner berdasarkan variabel fisiologi yang telah diperoleh.

\section{Distribusi dan Pengumpulan Data}

Kuesioner ini didistribusikan kepada tenaga kerja konstruksi (tukang) di beberapa proyek konstruksi di Jakarta. Data yang diperoleh sebanyak 50 responden dengan karakteristik usia dan bidang pekerjaan.

\section{Analisis Data}


Widoyoko (2012) mengatakan bahwa kuesioner merupakan salah satu teknik pengumpulan data yang dilakukan dengan cara memberikan sejumlah butir pertanyaan atau pertanyaan tertulis kepada responden dengan tujuan untuk mendapatkan tanggapan yang sesuai dengan keinginan dari tujuan penelitian yang sedang dilakukan. Kuesioner dilakukan apabila jumlah responden cukup banyak dan tersebar di daerah yang relatif luas, kuesioner juga merupakan metode yang efisien apabila variabel untuk penelitian telah diketahui secara pasti dan mengetahui apa yang bisa diharapkan dari responden.

Mengolah data atau analisis faktor dengan menggunakan program SPSS (Statistical Program for Social Sciences) 21.0. Tahapannya ialah:
a. Uji Validitas dan Reliabilitas
b. Analisis Faktor menggunakan uji KMO-MSA (Kaiser-Meyer-Olkin Measure of Sampling Adequacy) dan Bartlett
c. Matriks Anti-Image
d. Rotated Componet Matrix

\section{HASIL DAN PEMBAHASAN}

\section{Uji Validitas dan Reliabilitas}

Uji validitas dan reliabilitas dilakukan untuk menunjukan tingkat kevalidan dan kepercayaan suatu instrument. Suatu instrument dikatakan valid apabila harga $r>0,273$ (untuk 50 responden), dan dikatakan reliable bila $>0,6$. Dari hasil uji validasi dan reliabilitas terhadap 21 variabel memenuhi syarat, sehingga dapat dilakukan analisis faktor.

\section{Analisis Data}

Uji KMO harus $>0,5$ untuk menyatakan kecukupan data (Widarjono, A. 2010) dan Bartlett $<0,05$ supaya terdapat korelasi antar variable. Hasil uji $\mathrm{KMO}=0,636>0,5$ (dapat dianalisis), Bartlett $=0$ $<0,05$ (dapat dianalisis), sehingga dapat dilakukan anti-image.

Terdapat nilai MSA (Measure of Samplingg Adequacy) dari setiap faktor untuk melihat faktor mana saja yang layak. Faktor dinyatakan layak apabila nilai MSA $>0,5$. Jika terdapat nilai MSA $<0,5$, maka keluarkan nillai dengan MSA terkecil dan lakukan kembali analisis faktor.

Dari hasil uji MSA, didapat anti-image diiterasi sebanyak 2 kali, yaitu pada iterasi 1, variabel yang hilang: (2) pekerjaan ringan, (4) beban kerja, (5) alat, (9) libur, (10) istirahat malam, (18) jarak antar bengkel ke proyek, (20) emosi.

Pada Iterasi 2, variabel yang hilang: (7) menyukai pekerjaan. Selanjutnya dilakukan rotated component matrix

Tahapan ini merupakan tahapan akhir dari analisis data, hasilnya ialah terbentuk 4 kelompok variabel laten baru yang berpengaruh terhadap tenaga kerja konstruksi:

Variabel 1: nafas terengah-engah, berdebar-debar, mudah lapar, banyak tenaga, pekerjaan melelehakan 
Variabel 2: pekerjaan berat, stress, lelah

Variabel 3: lingkungan udara segar, berkeringat, jarak rumah ke proyek

Variabel 4: mental, menyukai pekerjaan

\section{KESIMPULAN DAN SARAN}

1. Dari hasil studi literatur berdasarkan penelitian terdahulu yang terdapat pada jurnal ASCE, terdapat 21 variabel terkait dengan diwakilkan 10 indikator faktor fisiologi terukur. Dari 21 (dua puluh satu) variabel terkait, hanya terdapat 13 (tigabelas) variabel terkait yang berhubungan dengan produktivitas.

2. Dari hasil analisis data didapatkan 4 kelompok variabel laten baru yang terbentuk, yaitu

a. Variabel 1, terdiri dari nafas_terengah-engah (konsumsi oksigen), berdebar_debar(denyut nadi), mudah_lapar (pengeluaran energi), banyak_tenaga (konsumsi oksigen, pengeluaran energi, denyut nadi), pekerjaan_melelahkan

b. Variabel 2, terdiri dari: pekerjaan_berat (pengeluaran energi), stress, lelah

c. Variabel 3, terdiri dari: lingkungan_udara segar (suhu tubuh), berkeringat (suhu tubuh), jarak_rumah ke proyek (ergonomi)

d. Variabel 4, terdiri dari: mental, menyukai_pekerjaan

3. Dari ke-4 kelompok variabel laten baru, didapatkan 7 indikator fisiologi yang berpengaruh terhadap tenaga kerja konstruksi yaitu konsumsi oksigen (nafas terengah-engah dan memerlukan banyak tenaga), denyut nadi (berdebar-debar dan banyak tenaga), pengeluaran energi (mudah lapar, dan banyak tenaga), stress, suhu tubuh (berkeringat dan lingkungan udara yang segar), ergonomi, dan mental.

\section{REFERENSI}

Abdelhamid, T. S., and Everett, J.G. (2002). "Physiological Demands During Construction Work." J. Constr. Eng. Manage., 128:427-437.

Astrand, P., and Rodahl, K. (1986). Textbook of Work Physiology, Physiological Bases of Exercise. New York: McGraw-Hill.

Brouha, L. (1967). Physiology in Industry. New York: Pergamon Press.

Castaneda, J., Tucker, R., Haas, C., Glover, R., and Shield, D. (2003). A Revolutionary and Structured Approach to Construction Work Force Management: The Tier II Strategy. Construction Research Congress 2003, ASCE, Reston, VA, 1-8. 
Castaneda, J., Tucker, R., Haas, C., Glover, R., and Shield, D. (2005). Worker's Skill and Receptiveness to Operate Under The Tier II Strategy Management Strategy. J. Constr. Eng. Manage., 10.1061/(ASCE)07333-9364(2005)131:7(799), 799-807.

Christensen, E., H. (1983). Physiology of Work in Encyclopedia of Occupational Health and Safety. (Editor: Parmeggiani, L., Switzerland: International Labor Organization).

Janaro, R. E. (1982). The Development and Implementation of Optimal Multi-rest Break Scheduling Models. Ph.D. Dissertation, Florida State University, Florida.

Jergeas, G. (2010). Top 10 Areas for Construction Productivity Improvement on Alberta Oil and Gas Construction Project. Cons. Research Project 2010, ASCE, Reston, VA, 1030-1038.

Song, L., AbdouRizk, S.M. (2008). Measuring and Modeling Labor Productivity Using Historical Data. J. Constr. Eng. Manage., 134:786-794.

Suharto, Imam. (1997). Manajemen Proyek, dari Konseptual sampai Operasional Jilid 1. Jakarta: Erlangga.

Wulfram, Ervianto, I. (2005). Manajemen Proyek Konstruksi (Edisi Revisi). Yogyakarta: ANDI. 